\title{
MORPHOLOGY OF THE WALLS OF THE CAVERNOUS SINUS OF Cebus apella (TUFTED CAPUCHIN MONKEY)
}

\author{
ROBSON JOSÉDE SOUSA DOMINGUES*, \\ JOSÉ AUGUSTO P. CARNEIRO MUNIZ**, OISENYL JOSÉ TAMEGA***
}

\begin{abstract}
The morphology of the dura mater and its relationship with the structures of the cavernous sinus were analyzed in five tufted capuchin monkeys (Cebus apella) using histological sections, showing that the walls of the cavernous sinus of this species are similar to those of other primates, including man. Except for the medial wall of the cavernous sinus, the remaining walls consist of two distinct dura mater layers. The deep layer of the lateral wall of the cavernous sinus is contiguous to the sheath of the oculomotor, trochlear and ophthalmic nerves. Arterioles, venules, venous spaces, neuronal bodies and nervous fiber bundles are found on this lateral wall.
\end{abstract}

KEY WORDS: cavernous sinus, cranial nerves, dura mater, primates, Cebus apella.

\section{Morfologia das paredes do seio cavernoso em Cebus apella (macaco-prego)}

RESUMO - A morfologia da dura-máter e sua relação com as estruturas do seio cavernoso, analisadas em cinco macacos-prego (Cebus apella) através de cortes histológicos, mostrou que as paredes do seio cavernoso nessa espécie são semelhantes a de outros primatas, inclusive o homem. Com exceção da parede medial do seio cavernoso as demais paredes são formadas de duas camadas distintas de dura-máter. A camada profunda da parede lateral do seio cavernoso está em continuidade com a bainha dos nervos oculomotor, troclear e oftálmico. Nesta parede lateral são encontradas arteríolas, vênulas, espaços venosos, corpos de neurônios e feixes de fibras nervosas.

PALAVRAS-CHAVE: seio cavernoso, nervos cranianos, dura-máter, primatas, Cebus apella.

The cavernous sinus is a small compartment located on both sides of the sella turcica between the layers of the dura mater ${ }^{1-3}$. Eyster ${ }^{4}$ was a pioneer in describing the anatomy of the cavernous sinus of Macacus rhesus. He reported that this sinus is a space containing fine trabeculae, nerves and some vessels, that these venous spaces communicate with each other and are lined with endothelium, and that the cavernous sinus of these animals is different from that of man by presenting a less evident cavernous aspect.

Little information is available about the characteristics of the walls of this sinus for New World monkeys. Studies on the region of the cavernous sinus of non-human primates are important because these are the closest relatives of man and because of their anatomical, biochemical, behavioral and physiological factors. Thus, theses animals represent useful models for comparative studies, especially concerning the diseases that affect human beings ${ }^{5}$.

* Professor do Departamento de Ciências Morfológicas e Fisiológicas da Universidade do Estado do Pará, UEPA; ** Médico Veterinário do Centro Nacional de Primatas, Pará, Brasil; *** Professor Titular da Disciplina Neuroanatomia do Instituto de Biociências (IB), Universidade Estadual de São Paulo (UNESP) Botucatu SP, Brasil. This research was supported by CAPES/PICDT-UEPA (Proc. $\mathrm{n}^{0}$ 022695). Aceite: 19-julho-1999.

Dr. Oisenyl José Tamega - Departamento de Anatomia, IB, UNESP - Rubião Júnior s/n - 18.618-000 Botucatu SP - Brasil. E-mail: oisenyl@ibb.unesp.br 
In the present study on Cebus apella (tufted capuchin monkey) we describe the morphology and content of the wall of the cavernous sinus and its relationship with adjacent structures using histological sections.

\section{METHOD}

Five adult tufted capuchin monkeys (Cebus apella) of both sexes weighing 2 to $3 \mathrm{~kg}$ obtained from the National Primate Center, Health Ministry, Pará, Brazil., were anesthetized with ketamine hydrochloride (Vetalar) administered intramuscularly at the dose of $10 \mathrm{mg} / \mathrm{kg}$ body weight. The animals were perfused with $0.9 \%$ sodium chloride by intracardiac injection and fixed with Bouin's solution. After craniotomy and brain removal, a portion of the skull base containing the sphenoid body, the hypophysis gland and the cavernous sinuses was divided into two blocks by a sagittal section and decalcified in 7.0\% EDTA, $\mathrm{pH} 7.0$, at room temperature for approximately four weeks. Each block was embedded in Historesin glycol methacrylate for the preparation of $5 \mu \mathrm{m}$ coronal sections, and stained with Masson trichrome and hematoxylin-eosin. Photographic documentation was obtained with an Olympus BH-2 photomicroscope.

\section{RESULTS}

The cavernous sinus of monkeys (Cebus apella) is a cavity delimited by the dura mater in a continuous manner through the superior, medial, inferior and lateral walls. This meningeal layer involves nervous, vascular and adipose elements.

The superior wall of the cavernous sinus (Figs 1 and 2) is formed by a dura mater fold consisting of dense connective tissue on the surface layer and of loose connective tissue in the deep layer. This fold surrounds the oculomotor nerve, is fixed on the anterior clinoid process and continues medially with the diaphragm of the sella turcica.

The dura mater of the medial wall of the cavernous sinus (Fig 2) corresponds to the lateral wall of the sella turcica, which separates this sinus from the hypophysis. Morphologically, it is a single layer formed of loose and irregular connective tissue presenting no vessels or nervous fiber bundles. This medial wall is relatively thicker when compared to the other walls of this sinus and is contiguous to the deep layer of the superior and inferior walls.

The inferior wall consists of dura mater juxtaposed to the lateral portion of the sphenoid bone. It presents a superficial layer formed of dense connective tissue and an irregular, fine and less defined deep layer consisting of loose connective tissue (Fig 1).

The lateral wall of the cavernous sinus presents a dura mater formed of two layers with distinct characteristics which differ in texture and content. The superficial layer consists of modeled dense connective tissue containing thick and compact collagen fiber bundles. The deep layer consists of loose connective tissue whose collagen fibers, of irregular aspect, are contiguous to the epineurium of the oculomotor and trochlear nerves and of the ohpthalmic branch of the trigeminus (Figs 3 and 4).

Arterioles, venules, neuronal bodies, nervous fiber bundles and small venous spaces of varied shape and size were found in the deep layer of the lateral wall of the cavernous sinus in all cases studied (Figs 4, 5, and 6).

The deep layer of the walls of the cavernous sinus participates in the delimitation of larger venous compartments lined with endothelium and present in the lumen of the sinus.

\section{DISCUSSION}

Few studies are available in the literature about the morphology of the cavernous sinus wall of New World primates, including Cebus apella. In humans $s^{3,6-8}$, in Macaca fascicularis ${ }^{9}$ and in rats ${ }^{10}$, the dura mater of the cavernous sinus consists of two layers. The histological study of this structure in Cebus apella permitted us to observe that the dura mater of the superior, inferior and lateral walls of the cavernous sinus also consists of two layers: a superficial one and a deep one. 


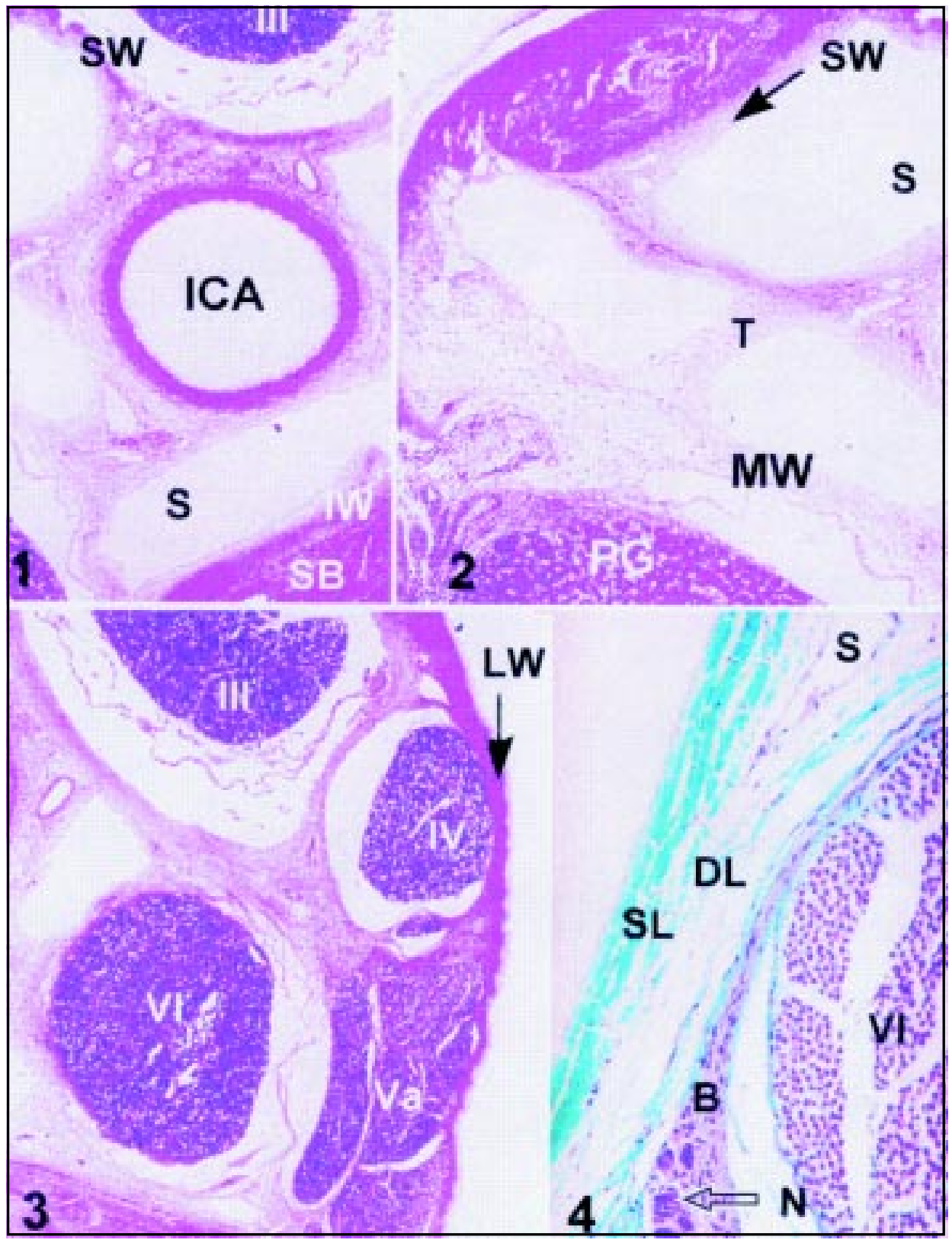

Coronal sections of the cavernous sinus of tufted capuchin monkey: Fig 1. Internal carotid artery (ICA), inferior wall (IW), venous spaces (S), sphenoid body (SB), superior wall (SW) and oculomotor nerve (III). H.E. $x$ 80. Fig 2. Medial wall $(M W)$, Pituitary gland $(P G)$, superior wall $(S W)$, venous spaces $(S)$ and trabeculae $(T)$. HE $x 113$. Fig 3. Lateral wall (LW), oculomotor nerve (III), trochlear nerve (IV), ophtalmic nerve (Va) and abducens nerve (VI). HE x 108. Fig 4. Nervous fiber bundles (B), deep layer of lateral wall (DL), neuronal bodies (N), venous spaces (S) superficial layer of lateral wall (SL) and abducens nerve (VI). Masson trichrome 209. 


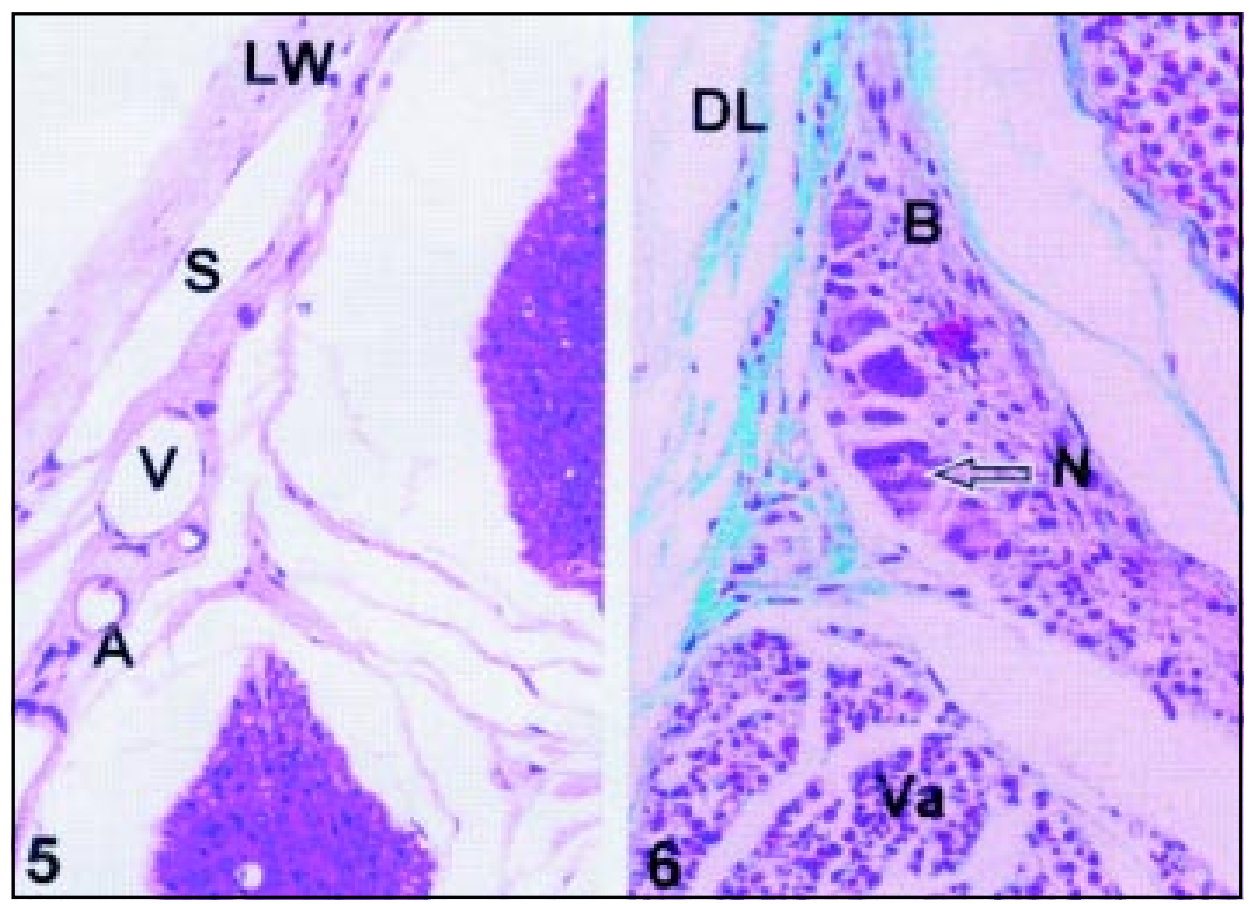

Lateral wall of the cavernous sinus of Cebus apella. Fig 5. Arteriole (A), lateral wall (LW), venous spaces (S) and venule (V). HEx 280. Fig 6. Nervous fiber bundles (B), deep layer (DL), neuronal bodies (N), and ophthalmic nerve (Va). Masson trichrome x 525 .

The double layer of the superior wall of the human cavernous sinus consists of a smooth superficial layer and a deep, fine and less defined deep layer ${ }^{11}$. A coronal sectional study of the cavernous sinus of Macaca fascicularis showed that the dura mater is clearly separated into a layer called endocranial and an endomeningeal layer in the middle cranial fossa. The separation and rejoining of these two layers form a meningo-osteal compartment at the base of the skull, the cavernous sinus, which presents distinct walls, i.e., a lateral wall, a medial wall, a narrow roof and a floor'.

In Macaco rhesus, the medial wall of the cavernous sinus is formed by the dura mater, which is in contact with the periostium of the sphenoid bone $e^{4}$. Due to the almost plane conformation of the inner surface of the base of the skull, the medial wall of the sinus of Cebus apella only separates the cavernous sinus from the hypophysis and consists of a thick layer of connective tissue with no vessels or nerve fibers. In Papio ursinus, Cercopithecus pygerithrus, Galago senegalensis ${ }^{12}$ and Macaca fascicularis ${ }^{9}$ the medial wall has been described as a fold of the dura mater separating the hypophysis from the cavernous sinus.

On the lateral wall, the deep layer prolongs to surround the cranial nerves associated with this region. In man, some investigators ${ }^{3,13}$ have described the deep layer as being simply a fine lining consisting of nerve sheaths which separates the sinus into a neural and a venous compartment, whereas others ${ }^{8}$ have detected venous spaces, arterioles, neuronal bodies and small nervous fiber bundles in this region.

Scanning electron microscopy showed that the medial and lateral walls of the cavernous sinus of humans ${ }^{14}$ consist of various dural layers with collagen fibers oriented towards different directions. It has been reported that in a human fetus ${ }^{15}$, the lateral wall of the cavernous sinus consisted of four layers. However, in tufted capuchin monkeys, we noted that the connective tissue of the 
sheaths of the oculomotor nerve is contiguous to the connective tissue of the deep layer of the lateral wall of the cavernous sinus and that this arrangement of the connective tissue may have led the above investigators to conclude that the lateral wall of the cavernous sinus consists of various layers.

In Cebus apella we detected neuronal bodies in the deep layer of the lateral wall of the cavernous sinus and between the abducens nerve and the ophthalmic nerve. In contrast, in man ${ }^{16}$ these cells are in the trabeculae of the cavernous sinus between the internal carotid artery and the abducens nerve; in Macaca fascicularis ${ }^{17,18}$ the cavernous plexus presents these cells forming small ganglions located along the ophthalmic nerve, with characteristics differing from those of the trigeminal ganglion; and in rats ${ }^{10}$ these neurons mainly occupy the lateral wall of the sinus.

In immunohistochemical studies of the pathways of sensory and autonomic nerves of Saimiri sciureus monkeys ${ }^{19}$, the cavernous ganglion was found to be localized inside the trabeculae of the sinus, presenting positive parasympathetic markers. These results led the authors to add that the possible connections of this ganglion are with the internal carotid artery, the abducens nerve, the ophthalmic nerve, the sphenopalatine nerve and the maxillary nerve. These authors also commented about the possibility that the cavernous ganglion is fragmented into multiple diminutive ganglions along its connections, forming a plexus inside the trabeculae located between the vessels of the cavernous sinus.

Acknowledgements - We thank National Center of Primates, Pará - Brazil by ceded animals.

\section{REFERENCES}

1. Bedford MA. The cavernous sinus. Br J Ophthalmol 1966;50:41-46.

2. Gray H. Anatomia. Ed37. Rio de Janeiro: Guanabara Koogan, 1980:1090-1092.

3. Umansky F, Nathan H. The lateral wall of the cavernous sinus. J Neurosurg 1982;56:228 234.

4. Eyster AB. The cavernous sinus in a macacus rhesus monkey. Anat Rec 1944;90:37-40.

5. Muniz JAPC, Ferreira H S, Castro PHG. Centro Nacional de Primatas "O endereço da vida". In Anais do XV Congresso Panamericano de Ciências Veterinárias. Campo Grande: 1996:71.

6. Sadasivan B, Ma SH, Dujovny M, Ausman JI, Zamorano L, Dragovic L. The anterior cavernous sinus space. Acta Neurochir 1991;108:154-158.

7. Kawase T, Van Loveren H, Keller JT, Tew JM. Meningeal architecture of the cavernous sinus: clinical and surgical implications. Neurosurgery 1996;39:527-535.

8. Chopard RP, Lucas GA, Venosa, A. Estudo micro-mesoscópico da parede lateral do seio cavernoso humano. Arq Neuropsiquiatr 1996;54:645-651.

9. Rajendran K, Ling A. Light and scanning electron microscopical study of the cavernous sinus of the monkey, Macaca fascicularis. J Anat 1985;140:229-235.

10. Bleys RLAW, Groen GJ, Hommersom RF. Neural connections sinus in rat, with special reference to cerebrovascular innervation. J Comp Neurol 1996;369:277-291.

11. Umansky F, Valarezo A, Elidan J The superior wall of the cavernous sinus: a microanatomical study. J Neurosurg 1994;81:914-920.

12. Lake AR, Van Niekerk IJM, Le Roux CGJ, Trevor-Jones TR, De Wet PD. Angiology of the brain of the Baboon Papio ursinus, the Vervet monkey Cercopithecus pygerithrus, and the Bushbaby Galago senegalensis. Am J Anat 1990;187:277-286.

13. Harris SF, Rhoton AL. Anatomy of the cavernous sinus: a microsurgical study. J Neurosurg 1976;45:169-180.

14. Wong A, Arnold R, Doran GA. A scanning electron microscopic investigation of the human cavernous sinus. Aust Dent J 1994;39:266

15. Vücetic R, Vücetic D. The layers of the lateral wall of the cavernous sinus. Acta Anat 1995;152:355.

16. Carvalho VC. Nerve cells in the human cavernous sinus. Anat Anz 1985;159:29-32.

17. Ruskell GL, Simons T. Trigeminal nerve pathways to the cerebral arteries in monkey. J Anat 1987;155:23-37.

18. Simons T, Ruskell LG. Distribution and termination of trigeminal nerves to the cerebral arteries in monkey. J Anat 1988;159:57-71.

19. Hardebo J E, Arbab M, Suzuki N, Svendgaard NA. Pathways of parasympathetic and sensory cerebrovascular nerves in monkeys. Stroke 1991;22:331-342. 